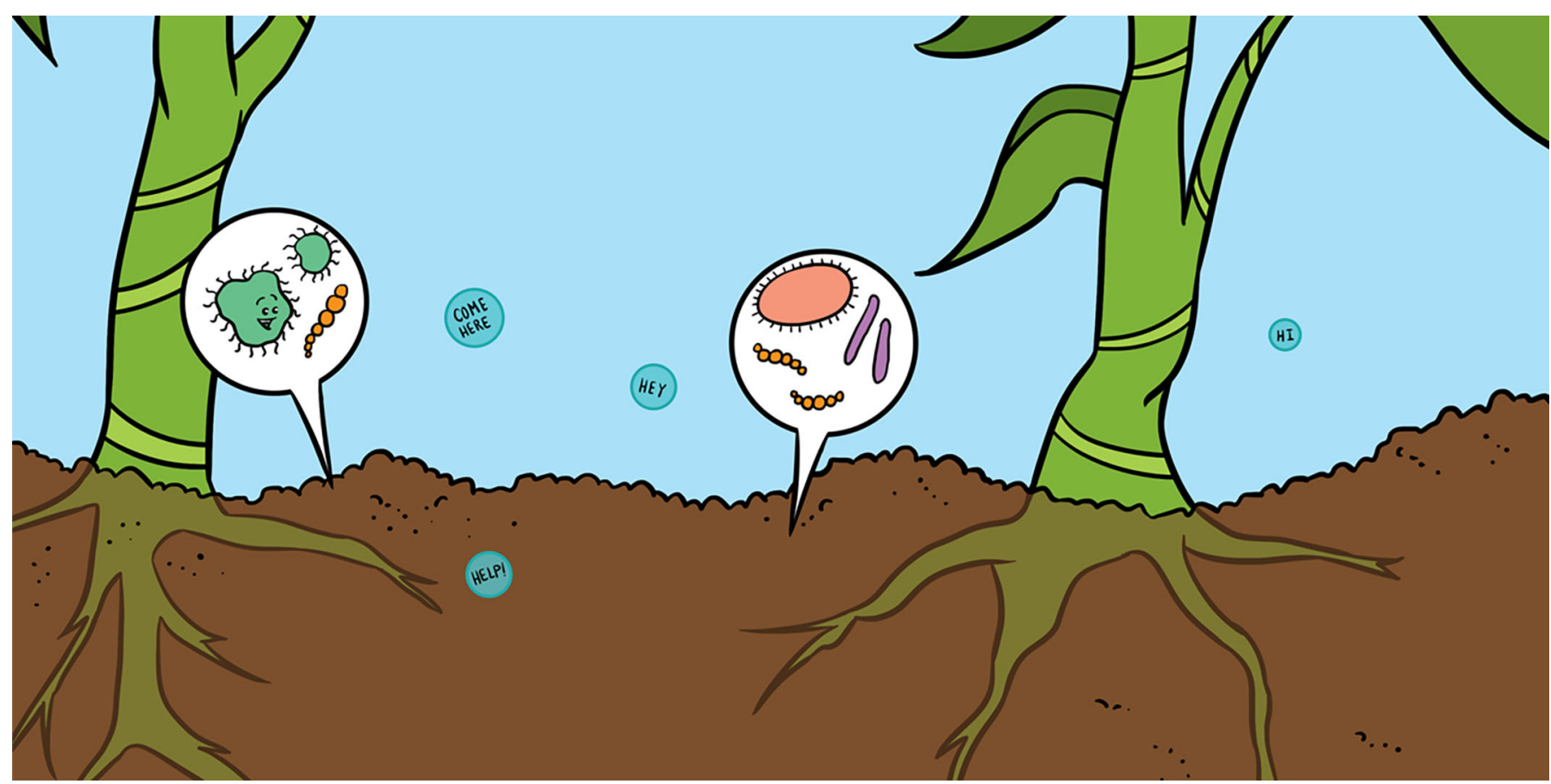

\title{
THE FASCINATING WORLD OF BELOWGROUND COMMUNICATION
}

\author{
Cristiana Ariotti ${ }^{1}$, Elena Giuliano ${ }^{1}$, Paolina Garbeva ${ }^{2}$ and Gianpiero Vigani ${ }^{1,2^{*}}$ \\ ${ }^{1}$ Plant Physiology Unit, Department of Life Sciences and Systems Biology, University of Turin, Turin, Italy \\ ${ }^{2}$ Department of Microbial Ecology, Netherlands Institute of Ecology (NIOO-KNAW), Wageningen, Netherlands
}

YOUNG REVIEWER:

SHASHI

PREETHAM

AGE: 13
If you are a microbe in soil, how do you say something to your neighbors? Well, speaking English, French, or Italian would not do you any good underground. Instead, you would have to use molecules as words! Soil microbes like bacteria and fungi communicate with each other and with other organisms, such as animals or plants, by producing different kinds of molecules. Many organisms use these molecules as chemical words. These molecules can be volatile molecules, which means that they are like gases, just like the air. They can travel easily through small pockets of air in the soil and can also travel really far. It is like long-distance communication. Other molecules are soluble so they can dissolve in water, allowing the communication between organisms close to each other. The organisms that receive this communication can respond in different ways, such as by growing faster or producing other molecules in response. In this article, we will explore the exciting and mysterious world of belowground chemical communication and its role in the interactions occurring between microbes and plants. 


\section{ECOSYSTEM}

The set of different organisms (plants, animals, and microbes) that interact with the non-living matter in a specific area.

\section{RHIZOSPHERE}

The portion of the soil surrounding the roots where plants and microbes talk to each other by using molecules.

\section{CHEMICAL}

\section{COMMUNICATION}

The communication that occurs between two or more different organisms (plants, animals, and microbes) by using molecules.

\section{SOLUBLE}

A substance that dissolve in water, like salt and sugar.

\section{VOLATILE}

A substance that tents easily to become gas and spread in the air, like the smell of a flower.

\section{LIFE IN THE SOIL}

The soil is one of the most fascinating and complex ecosystems on Earth. It is not only the outer surface of our planet where plants grow, but it is also a spectacular and hidden world where many kinds of organisms live. The soil is composed of irregular pieces of rocks, small air-pores, and organic matter (dead plants and animals). This environment is a wonderful place for microbes, insects, and plants to live. Can you believe that soil is so full of life? Depending on the soil characteristics (size of the rocks, types of food, amount of water, etc.), different organisms can live in it. These different organisms build a specific community, which is a unique set of different organisms living together.

Do you know what soil microbes are? They are very tiny organisms that live attached to soil particles or other living things. There are fungi that have a shape similar to very thin roots, so that they can touch and exchange information with their neighbors. There are also bacteria, which are organisms that consist of a single cell that you can usually see only by using a microscope. If these organisms live in the rhizosphere (the portion of soil surrounding the plant roots), they are called rhizosphere microbes. They can also live on the root surface or inside the roots [1]. In the rhizosphere, you can find beneficial (good) microbes, which help plants to survive and grow, or harmful (bad) microbes, which attack plants and make them sick.

\section{HOW DO SOIL MICROBES AND PLANTS COMMUNICATE?}

What is particularly exciting is the ability of soil microbes to communicate amongst themselves as well as with other organisms, including plants and animals. The communication between microbes and plants has been studied by many scientists. This communication is based on the use of molecules as words, and it is called chemical communication. You can imagine a molecule as a group of many little balls (that we call atoms), connected to each other. These atoms are important chemical pieces, like carbon (C), hydrogen $(\mathrm{H})$, oxygen $(\mathrm{O})$, and nitrogen $(\mathrm{N})$, that join together (like a puzzle) to form molecules like water $\left(\mathrm{H}_{2} \mathrm{O}\right)$ or carbon dioxide $\left(\mathrm{CO}_{2}\right)$. The specific combination of atoms creates molecules that have different properties.

Soil microbes can produce many types of molecules, which can be divided into two main categories: soluble molecules and volatile molecules. Soluble molecules dissolve in water, like a sugar cube in tea, and they can be transported by water in the soil. They are used to talk with plants that grow close to the microbes. Volatile molecules, also 
Figure 1

Plant-microbe interactions in the rhizosphere. The picture shows three types of

interactions: (A) interactions between plants and microbes living on the root surface or near the roots, with the help of soluble molecules; (B) interactions between plants and microbes living far away from the roots, with the help of volatile molecules; and (C) interactions with microbes living inside the roots, directly in contact with root cells These interactions take place in the soil, which is composed of rocks, air pores, and organic matter.

\section{VOCS}

The volatile organic compounds that are produced by different organisms, like plants and microbes, to communicate with each other by distance.

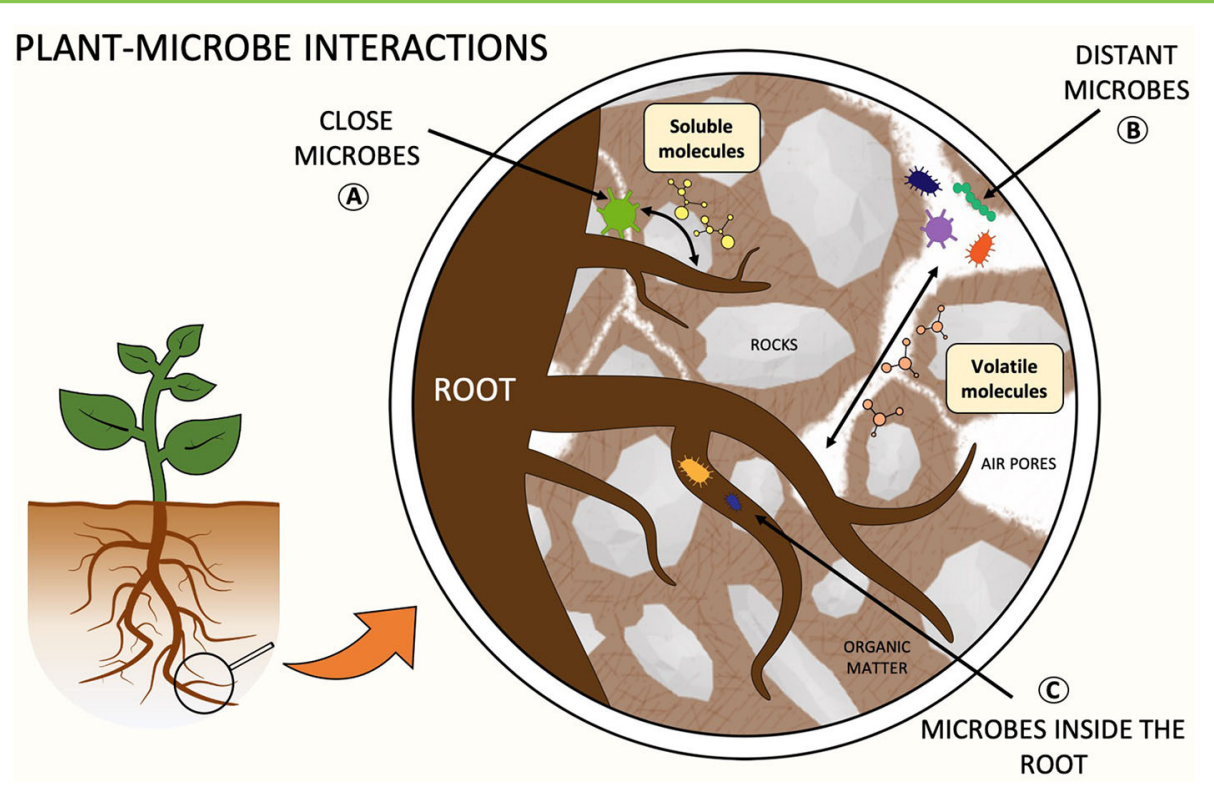

Figure 1

called volatile organic compounds (VOCs), are used to communicate over long distances (Figure 1). These volatile compounds are gases, which travel easily through the air-pores of the soil. Plant roots can smell these gases, like your nose can smell a flower or freshly baked bread [1]. Chemical communication does not happen only in one direction (from the microbes to the plants), but in two directions-plants also produce molecules that can be understood by microbes.

\section{WHAT ARE THE EFFECTS OF COMMUNICATION MOLECULES?}

Here are some examples of what happens between microbes and plants when they start to talk to each other.

\section{Plants and Microbes Help Each Other to Get Food}

Many soil microbes can help plants grow, because the microbes make necessary nutrients more available for the plants. For example, a bacterium called Rhizobium can transform the nitrogen in the air $\left(\mathrm{N}_{2}\right)$ into a different molecule: ammonia $\left(\mathrm{NH}_{3}\right)$. This transformation is called nitrogen fixation and it happens in the soil. Nitrogen fixation is really important for plants because they need nitrogen to grow and they are only able to get $\mathrm{NH}_{3}$ from the soil. By transforming $\mathrm{N}_{2}$ into $\mathrm{NH}_{3}$, Rhizobium helps plants to grow and makes them stronger!

What is even more interesting is that Rhizobium can talk with a specific group of plants, including beans and peas. But how does this dialogue work? First, the plant releases molecules called isoflavones into the rhizosphere, which can attract Rhizobium. The bacteria "hear" the 
Figure 2

The effects of plant-Rhizobium interactions on root structure. (A) Normal root structure and the beginning of chemical communication. First, the plant produces isoflavones (1), then Rhizobium responds by producing nod-factors (2). (B) Rhizobium goes toward the root and sticks to a root hair, which then changes its shape to hug the bacteria so that the bacteria can enter into the root. (C) Formation of the root nodule, which is the space where the bacteria multiply and sugar and nitrogen are traded.

\section{BIOTIC FACTORS}

The living components of an environment, like plants, animals, and microbes.

\section{ABIOTIC FACTORS}

The non-living components of an environment, like rocks, sunlight, and water.

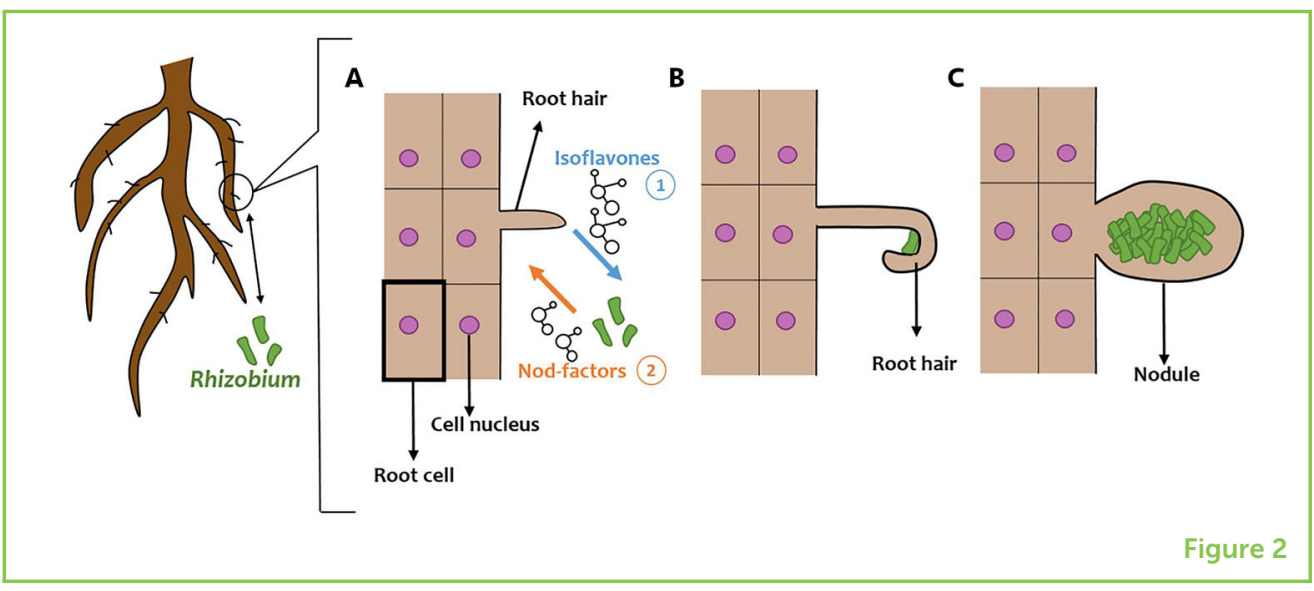

plant "talking" and go toward it. On their journey toward the plant, the Rhizobium start to produce other molecules, known as nod-factors, which tell the plant to create a space in the roots, called root nodule, where the Rhizobium can live. In exchange for a place to live and food (sugar) from the plant, the Rhizobium gives the plant a lot of $\mathrm{NH}_{3}$ (Figure 2). As a result, plants that allow Rhizobium to live with them grow much more. For both the plant and the Rhizobium, living together is an advantage, because both organisms have more food to eat than when they live alone, and thus they can grow better [2].

\section{Microbes Can Help Protect Plants From Pathogens and Pests}

Biotic factors are the living parts of an environment, such as plants, animals, and microbes (Figure 3). Biotic stress is stress felt by an organism, like a plant, that is damaged by biotic factors like bad microbes, called pathogens, or by bad insects, called pests. Good microbes can help plants to fight against pathogens and pests in two ways. First, the microbes can push the pathogen/pest away or kill it. For example, some good microbes produce VOCs that can stop a pathogen's growth or a pest's attack on the plant. The second way good microbes can help plants to fight pathogens is by telling the plant to prepare itself to fight by increasing its defenses. Probably also your mum, during the winter, tells you to eat oranges because they contain an important molecule, the vitamin $C$, which is able to increase your immune defenses protecting you from illnesses. The mechanism is the same for microbes and plants! For example, the molecules produced by the bacterium Pseudomonas fluorescens allow the plants to better resist the pathogen attack [3].

\section{Microbes Can Help Plants Survive in Difficult Areas}

Abiotic factors are the non-living parts of an environment, which include sunlight, temperature, and water (Figure 3). Abiotic stress is the negative effect of such factors on a living organism. Examples of abiotic stresses that weaken plants are low water availability and high levels of salt. Good microbes can help plants to live in difficult areas with bad living conditions. For example, the bacterium Pseudomonas 
Figure 3

Important biotic factors and abiotic factors that interact in the environment. They have an impact on plants growth and they can influence the chemical communication between plants and microbes in the soil. Mushroom icon is from Flaticon.com

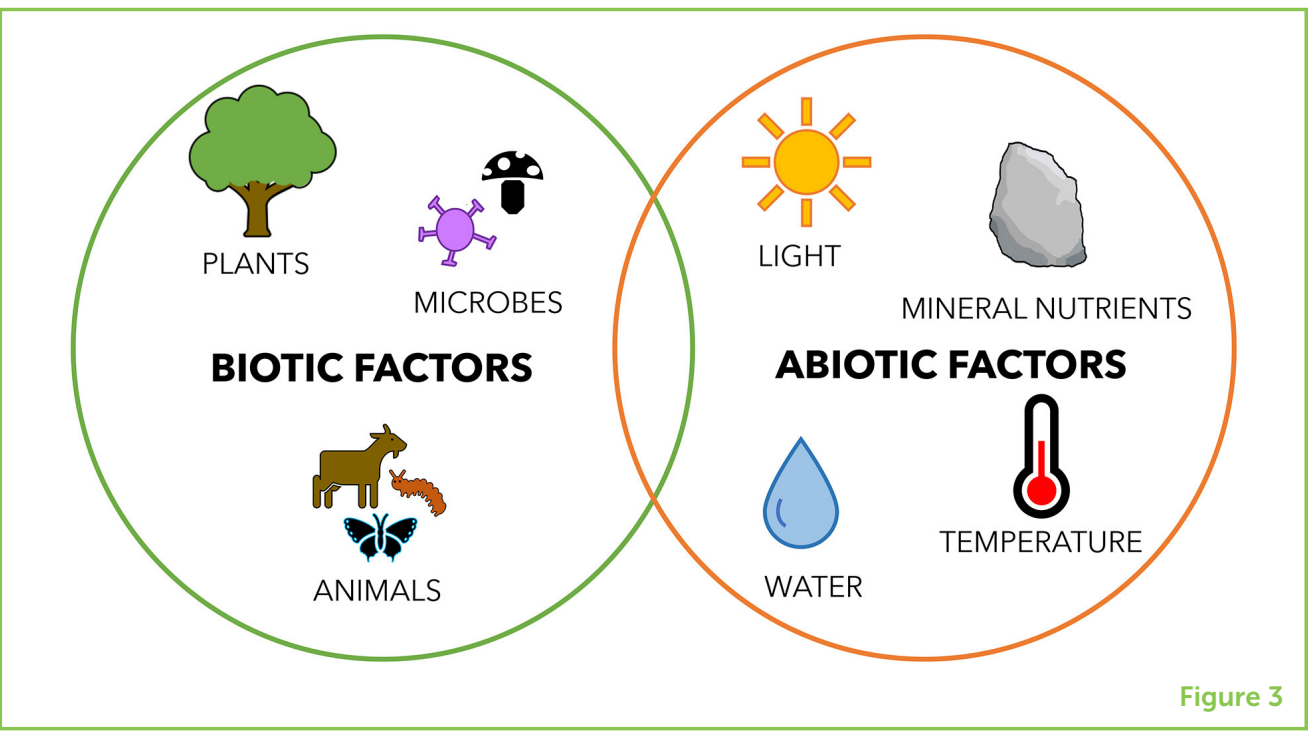

chlororaphis 06 allows some plants to survive when there is not enough water [4]. Other microbes, like the bacterium Bacillus subtilis, help plants to survive in soil where there is a high concentration of salt, by reducing the amount of salt that enters the plant's roots [5].

\section{WHY IS IT IMPORTANT TO UNDERSTAND CHEMICAL COMMUNICATION?}

Chemical communication between microbes and other organisms started evolving millions of years ago. Four hundred and fifty million years ago, plants moved from the sea and started to live on the land. Scientists believe that soil fungi first helped plants to make this move to land. The fungi helped the plants to use important nutrients so that the plants could survive [6]. So, for millions of years, chemical communication among soil organisms has been important for plant well-being and growth. In this article, we explained how plant-microbe interactions can give a plant more food or help plants to fight against pathogens or to live in difficult areas. Unfortunately, these interactions are in danger! The high use of antibiotics, pesticides, and fertilizers in agriculture can change the soil and in doing so can also change the soil community, causing some soil organisms to die and others to grow. Changes in the microbial community can have terrible effects on plants; for example, the microbes that grow might be pathogens!

The human population is still growing, and since people need food to survive, new methods of increasing plant growth and food production must be found [2]. Microbes are increasingly used as natural helpers to improve plant growth and food production. The study of microbe-plant communication is necessary to understand which microbes can be used to help plants grow. We must pay close attention to choose the correct microbes! For example, you could 
think that the use of the fungus Fusarium culmorum would be a good idea, because it helps certain plants to grow in difficult areas that are rich in salt. However, Fusarium culmorum is a bad organism for maize-it is a pathogen! For these reasons, researchers want to understand as much as possible about chemical communication, to increase our knowledge about soil ecosystems, to understand how organisms interact in these ecosystems, and to help us use plant-microbe interactions to increase plant growth for food while protecting soil ecosystems.

\section{REFERENCES}

1. van Dam, N. M., Weinhold, A., and Garbeva, P. 2016. Calling in the dark: the role of volatiles for communication in the rhizosphere. ISME J. 12:1252-62. doi: 10.1007/978-3-319-33498-1_8

2. Tomer, S., Suyal, D. C., and Goel, R. 2016. "Biofertilizers: a timely approach for sustainable agriculture," in Plant-Microbe Interaction: An Approach to Sustainable Agriculture, eds D. Choudhary, A. Varma, and N. Tuteja (Singapore: Springer). p. 375-95. doi: 10.1007/978-981-10-2854-0_17

3. Van Wees, S. C. M., Van der Ent, S., and Pieterse, C. M. J. 2008. Plant immune responses triggered by beneficial microbes. Curr. Opin. Plant Biol. 11:443-8. doi: 10.1016/j.pbi.2008.05.005

4. Garbeva, P., and Weisskopf, L. 2020. Airborne medicine: bacterial volatiles and their influence on plant health. New Phytol. 226:32-43. doi: 10.1111/nph.16282

5. Ortíz-Castro, R., Contreras-Cornejo, H. A., Macías-Rodríguez, L., and López-Bucio, J. 2009. The role of microbial signals in plant growth and development. Plant Signal. Behav. 4:701-12. doi: 10.4161/psb.4.8.9047

6. Field, K. J., Pressel, S., Duckett, J. G., Rimington, W. R., and Bidartondo, M. I. 2015. Symbiotic options for the conquest of land. Trends Ecol. Evol. 30:477-86. doi: 10.1016/j.tree.2015.05.007

SUBMITTED: 31 March 2020; ACCEPTED: 01 September 2020; PUBLISHED ONLINE: 20 October 2020.

EDITED BY: Rémy Beugnon, German Centre for Integrative Biodiversity Research (iDiv), Germany

CITATION: Ariotti C, Giuliano E, Garbeva P and Vigani G (2020) The Fascinating World of Belowground Communication. Front. Young Minds 8:547590. doi: 10. 3389/frym.2020.547590

CONFLICT OF INTEREST: The authors declare that the research was conducted in the absence of any commercial or financial relationships that could be construed as a potential conflict of interest.

COPYRIGHT @ 2020 Ariotti, Giuliano, Garbeva and Vigani. This is an open-access article distributed under the terms of the Creative Commons Attribution License (CC BY). The use, distribution or reproduction in other forums is permitted, provided the original author(s) and the copyright owner(s) are credited and that the original 

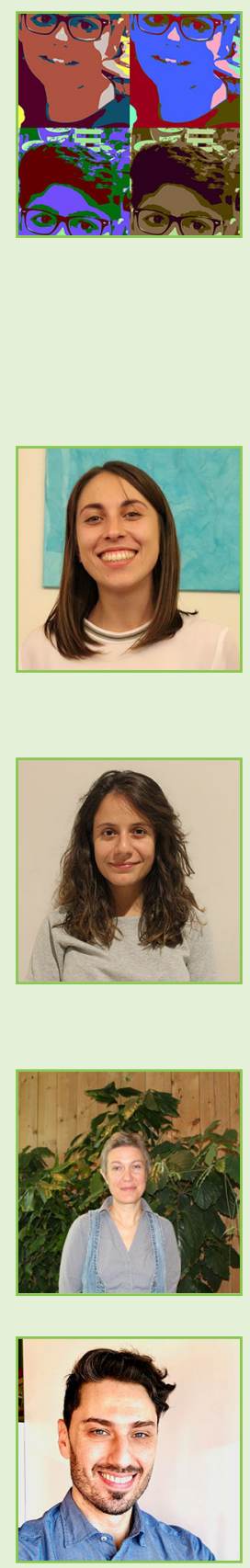

publication in this journal is cited, in accordance with accepted academic practice. No use, distribution or reproduction is permitted which does not comply with these terms.

\section{YOUNG REVIEWER}

\section{SHASHIPREETHAM, AGE: 13}

Hello, my name is Shashi, I am 13 years old and I go to Penglais School. I enjoy playing football and basketball. My favorite subjects are Maths and computers. I am currently studying year 8. I am a four times Guinness World Records holder in a game called Rocket League and my name is in 2018 Guinness World Record Gamers Edition.

\section{AUTHORS}

\section{CRISTIANA ARIOTTI}

I recently graduated from the University of Turin with a degree in Environmental Biology. I am now a Ph.D. student at the University of Turin where I study the communication between plants and soil microbes growing in iron-deficient conditions. In my free time, I love climbing mountains (I live near the Alps!) and singing in choirs.

\section{ELENA GIULIANO}

I recently graduated in Environmental Biology from the University of Turin. I would like to apply for a Ph.D. in plant science. I am interested in plant-microbe interactions and plant protection against biotic and abiotic stress. I like sharing knowledge and ideas with people from different cultures and I love reading and taking photos in my spare time.

\section{PAOLINA GARBEVA}

I am group leader in the Department of Microbial ecology at NIOO in Wageningen. The focus of my current research is to understand the fundamental mechanisms of microbial chemical interactions and communication.

\section{GIANPIERO VIGANI}

I am researcher at University of Turin (Italy). The focus of my research is to understand how plants take up nutrients and water from the soil and how plant-microbe interactions belowground occur. *gianpiero.vigani@unito.it 